\title{
Necessity of Cultural Historical Heritage Education in Social Studies Teaching
}

\author{
Tulay Ocal \\ Faculty of Education, Social Studies Education, Nigde University, Nigde, Turkey \\ Email: tocal@nigde.edu \\ Received 14 February 2016; accepted 11 March 2016; published 14 March 2016 \\ Copyright (C) 2016 by authors and Scientific Research Publishing Inc. \\ This work is licensed under the Creative Commons Attribution International License (CC BY). \\ http://creativecommons.org/licenses/by/4.0/ \\ (c) (i) Open Access
}

\begin{abstract}
This is accumulated on regions where the geography is suitable; cultures are rare heritages that are passed on from generation to generation. People have created and shaped these and preserved them as material and nonmaterial cultural accumulations through generations. Our ancestors have entrusted this heritage to pass on to the future generations. Reflecting the people and their activities vividly, cultural historical heritages are also the cultural changes people establish on earth. These cultural changes prepared by geography form cultural historical heritages over time. Government institutions and civil organizations have been working to pass on these cultural historical heritages to the future generations. However, their work is not sufficient and these heritages are getting destroyed. For the protection of these heritages and passing them on to the future generations, great responsibilities fall to universities and especially to the teacher candidates studying in education faculties. In particular, more responsibility fall to the teacher candidates attending social studies education departments of education faculties because subjects about cultural historical heritage are found in middle school social studies curricula and the social studies standards emphasize this subject. However, there is no course solely about cultural historical heritage in universities' social studies education departments. The history and archeology courses are taught as compulsory or elective courses in social studies education departments. Turkey, with a very old history and innumerable cultures, should be more aware about the importance of this issue. In this study, all the courses provided in Turkey's social studies education departments are examined and found that they are insufficient. Therefore, cultural historical heritage courses should be provided as compulsory courses to the teacher candidates and these courses' content should be organized to include Turkey's cultural historical because social education teachers play a big role in educating the future generations.
\end{abstract}

\section{Keywords}

Cultural Historical Heritage, Social Studies Education, Cultural Historical Heritage Education 


\section{Introduction}

Accumulated on regions where the geography is suitable, cultures are rare heritages that are passed on from generation to generation. People have created and shaped these and preserved them as material and nonmaterial cultural accumulations through generations. Hence, we must really understand what cultural historical heritage means and must fulfill our responsibilities to protect them.

Culture is the life style of a group of people who live in a particular place at a particular time (Zimolmak \& Stansfield, 1983). Culture is dynamic. Passed on from their ancestors, each generation changes this culture and adds new elements. Thus, sociologists consider not only a society's music, literature and art as culture but also a society's every aspect like clothing, habits, food preferences, architecture, shape of their farms and fields, education and legal system. Furthermore, culture is not only a mosaic reflecting people's life style but is a comprehensive concept covering values and beliefs (Tümertekin \& Özgüç, 2015).

As a learned behavior, culture is passed on from generation to generation with its entirety through cultural norms and each generation changes this inherited culture and adds new elements. In this context, cultural geography studies cultural groups and spatial diversity in terms of society's spatial functioning (Tümertekin \& Özgüç, 1997). The diversity of the laces people chooses for living reflects onto people’s lifestyles and culture. Culture is everything that people produces against the nature with the nature (Güvenç, 1994). Cultural geography, a combination of culture and geography, puts forth the cultural groups and spatial diversity in terms of society's spatial functioning with a geographical approach (Emekli, 2006). One of the key elements that constitutes nations is what we call material and nonmaterial values (Alım, 2009). The scientists who mention culture as an accumulation of material and nonmaterial values also argue that culture is an accumulation of present knowledge of the society (Uygur \& Baykan, 2007). Culture is a subject that social sciences like social psychology, history, sociology and ethnology discuss commonly. Of course, each of these disciplines explores culture with its aspects that concern them. In this case, culture is studied from different social science perspectives and defined accordingly (Gülcan, 2010). In geography, cultural processes (people's thoughts and lifestyles) and products produced as a result of these processes (buildings, crafts, art and traditions) are discussed under culture (Aliağaoğlu, 2004; Çetin, 2010; Öcal, 2014).

Studies on cultural heritage, consisting of material and nonmaterial values created by spatial differences, and conventions concerning preservation are becoming increasingly important (Emekli, 2006) because cultural heritage and historical sources are guarantees of not only our past but our future. Historical and archeological sites, protected urban historical sites, monuments, ruins, tumulus, mosques, churches make up cultural heritage and these elements should be under protection by laws (Doğaner, 2003). Historical sources, at the same time, are the physical remains of the past civilizations and periods. As having the remains belonging to world's first civilizations, cities should be protected places. The higher the number of old buildings in cities, the stronger the historical structure of them and more attractive the geographical appearance of them (Özgüç, 2003). Teachers play an important role in ensuring the continuity of attractiveness of this historical cultural heritage and passing on this heritage to future generations.

Historical cultural heritage sources are massive and are versatile life accumulations. Existing without any threats in the past, historical cultural heritages have been largely destroyed today and has faced with total destruction (Uygur \& Baykan, 2007). This historical cultural environment can be defined as images of reflections of cultural values created by people throughout history on physical environment (Keleş, 1997). These images are witnesses of their periods and information sources that tell us about the characteristics of those periods. Since these historical cultural values contribute to humanity's common pas, they must be places to be protected (Yasin, 2007). The problem of protecting these values start from the local and goes up to global. Developed policies about preservation has been tried to be kept alive. Preservation of historical cultural heritage has gained importance in the last 20 years and not only new implementation types have been developed but also new concepts have been developed (Herbert, 1995). In fact, there are international institutions and conventions developed to protect cultural artifacts in accordance with common principles of cultural heritage (Emekli, 2005). UNESCO accepted these cultural elements as tangible cultural heritage with 1972 UNESCO Convention Concerning the Protection of the World Cultural and Natural Heritage (UNESCO, 1972). On September 11, 1999, the European Union started “Europe a Common Heritage” campaign in a meeting held in Bucharest. The campaign's purposes are increasing cultural, natural and historical heritage awareness in Europe, developing cooperation among countries while respecting cultural diversity and bringing moral, religious and cultural values related to protected cultural and historical sites into the forefront. Other world institutions, companies, associations and vo- 
luntary organizations support this campaign (UNESCO, 1999). Protection of historical cultural heritage should be considered in the framework of sustainable development, pursuing the balance. For this purpose, Convention Concerning the Protection of the World Cultural and Natural Heritage is constantly being updated and other countries' signatures are being campaigned. Signing the UNESCO Convention Concerning the Protection of the World Cultural and Natural Heritage in 1983, our country has been working on many studies under Directory General of Preservation of Natural Heritage (Emekli, 2005).

While there are many studies under way in the world, countries like Turkey that are rich in historical cultural heritage focus more on heritage studies. In a survey study conducted with Spanish elementary and middle school teachers regarding cultural heritage and cultural heritage education, the following results were discovered: The responses given by middle school history and geography teachers show that cultural heritage is their knowledge levels about this subject are high. However, physics and chemistry teachers' knowledge levels about is lower than history and geography teachers. Biology, geology and grade teachers' knowledge levels about cultural heritage are even lower than the chemistry and physics teachers. Courses about historical cultural heritage taken by history and geography teachers during their undergraduate schooling are given as reasons behind this difference (Giménez et al., 2008). In recent years, historical cultural heritages are being collected in archives electronically in all the developed European countries. In European institutions, museums, archives and libraries, cultural heritages have been transformed into digital collections. These digital sources are being used for educational purposes. For example, teachers have been using them in teaching activities related to historical cultural heritage (Ott \& Pozzi, 2011). Especially in Italy, the subject of heritage has been given pedagogically and this led to computerized education in cultural heritage education (Ott \& Pozzi, 2008). Moreover, it is important for people living in historical environments to have the want and awareness to pass on this environment to the future generations (Ahunbay, 2007). When these people are taught the value of this historical environment, they will learn the importance of this environment and they will try to protect this environment (Stone, 2004). Staking a claim to this historical cultural heritage in Turkey is more than storing and displaying them. Without increasing the sensitivity and awareness levels of the society, historical cultural heritage works will not be protected (Aktekin, 2010; Dönmez \& Yeşilbursa, 2014).

Some museums throughout the world were founded as "educational museums" since the mid-19 century (Hooper-Greenhill, 1994). The first educational museum in the world, Haslemere Museum, was opened in 18941895 (San, 1998). Art education through museums emerged in the $19^{\text {th }}$ century in the West. The European museums became centers that collect information about the area, protect the nature and conduct social and cultural studies (Atasoy, 1978). Children museums have a long history in America where the first children museum was founded (Hooper-Greenhill, 1994; Şahan, 2005). Museums are non-profit living places that deals with archeology, art, science and people, collects, protects and displays any kind of product in people's lives, becomes a bridge between the past and the future, provide entertainment to people with its education, information and research opportunities and supports learning and creativity. They are universal and have continuity (Mercin, 2002). In many countries and our country, museums have sustainability policies. While in some countries museums are autonomous in every aspect, in other countries, including Turkey, they work under a ministry (Taş \& Y1ldız, 2015). For example, in England museums and protected historical sites have resorted to many new methods to promote themselves. In Museums, displays and shows are increasing because of computer programs that can spread light and sound. Furthermore, protected historical sites are using actors in historical costumes to promote the sites (Corbishley, 2000; Güleç \& Alkış, 2003). Since the Hittites, Sumerians, Urartians, Lydians, Phrygians, Ionians, Romans, Byzantines, Seljuks and Ottomans left uncountable traces and remains, our country is like an open museum. Each of our seven geographical regions has unique importance because of its natural beauty, historical remains and rural and urban sites. A total of 2,634,662 works are being displayed in 191 museums and 115 archeological sites under Turkish Ministry of Culture and Tourism (Emekli, 2005). In this context, the General Directorate of Turkish Cultural Artifacts and Museums worked hard and our 10 cultural artifacts were added to the UNESCO World Heritage List. 26 provisional artifacts were added to the UNESCO World Heritage List and Turkey implemented many national projects through non-governmental organizations (www.kulturvarliklari.gov.tr). There are many ancient cities, remains, archeological sites, churches and monasteries in Anatolia that has hosted numerous civilizations for thousands of years. Since Turkey is filled with historical cultural richness, these heritage works should be preserved and passed on to the future generations. However, this will only be possible with education and an informed society. Because it will be the teachers who will inform the society, courses about historical cultural heritage should be provided to teachers to make them 
understand the importance of historical cultural heritages.

\section{Study Purpose}

The purpose of this study is to identify what can be done to train teacher candidates so that they can raise future generations whose historical cultural heritage sensitivity and awareness levels are high.

1) What can be done across the country to middle school social studies teachers who are responsible for raising these students so that they have higher historical cultural awareness and knowledge levels?

2) How can the academic knowledge levels of social studies teacher candidates studying in education faculties across Turkey be increased?

\section{Study Method}

In this study, survey model, one of the quantitative research methods, was used. According to Cohen et al. (2009), surveys collect data at a specific point in time with the intention of describing the nature of an existing condition. Furthermore, the event, individual or object that is being studies is described in its natural environment. No effort to change or affect them is made. What needs to be learned exists and it is there. What is important is to observe it appropriately and identify it (Karasar, 2014). In this study, the elective courses related to historical cultural heritage education given in all of the Social Studies Departments of Turkish universities education faculties were scanned and their adequacy for teacher candidates was discussed.

\subsection{Study Universe and Sample}

The departments of social studies education of education faculties in Turkey make up the universe of the study. The elective courses related to historical cultural heritage education taught in social studies education departments of education faculties in Turkey constitute the sample of the study. These courses are courses like Historical Cultural Heritage, World Heritage Regions and Tourism Culture Geography, Turkish Cultural History and Civilizations History.

\subsection{Data Collection Tool}

At the beginning of the study books and articles about historical cultural heritages and studies about how these can the taught in social studies education departments were examined. Particularly studies about teacher candidates’ academic knowledge levels of historical cultural heritage were examined in detail (Giménez et al., 2008; Sternberg, 1989; Alkış \& Oğuzoğlu, 2005; Kılcan \& Akbaba, 2013; Işık, 2008; Aktın, et al., 2013; Ott \& Pozzi, 2008; Dönmez \& Yeşilbursa, 2014; Yeşilbursa, 2013; Gümüş \& Adanal1, 2011). The Turkish middle school social studies curricula and its content were examined. Although the course curricula are not adequate, students are being provided practical education in historical environments through projects. The projects of the Foundation for the Protection and Promotion of the Environment and Cultural Heritage were examined for this study. Founded in 1990 by volunteer academicians, this foundation is creates projects by traveling cities and does promoting works towards elementary and middle school students about the historical cultural heritage found in their cities. Implemented with European partners, Outdoors Education Project is a project that teaches middle school students about historical cultural heritage at outdoors with ecological and sport activities. The project, also, tries to find ways to relate these sites with student groups.

\subsection{Data Analysis}

In the study, whether the subjects related to historical cultural heritage in elementary and middle school is adequate or not was examined. The subjects in $5^{\text {th }}$ grade social studies were examined. Also, historical cultural heritage elements in $7^{\text {th }}$ grade social studies curricula were explored in detail. Elective courses that were provided in universities to social studies teacher candidates who will teach social studies to future generations.

\section{Findings and Interpretations}

Two sub-problems were determined to identify what can be done to train teacher candidates who are responsible for raising students so that they have higher historical cultural awareness and cultural levels. Using survey de- 
sign, course contents of social studies departments of education faculties and middle school social studies curricula were examined in detail.

\subsection{Course Contents of Middle School Social Studies Curricula and Studies Conducted}

When the social studies course contents of middle schools in Turkey are examined, subjects related to historical cultural heritage are found in the $2^{\text {nd }}$ and $8^{\text {th }}$ units of $5^{\text {th }}$ grade. These units appear to be compressed inside other subjects. In the $3^{\text {rd }}$ unit of $7^{\text {th }}$ grade, Ottoman historical cultural heritage is being taught. Also, subjects about historical cultural heritage are included inside the $7^{\text {th }}$ unit, titled International Bridge, of $7^{\text {th }}$ grade. However, when the objectives for this unit are examined, it is seen that historical cultural heritage subjects are not adequate but instead superficial.

When the educational objectives for these subjects are examined in detail, the following is found: The $2^{\text {nd }}$ unit of $5^{\text {th }}$ grade explores historical cultural heritage. The unit is titled Step by Step Turkey. The first four objectives of this unit is directly about Turkey's historical cultural heritage. According to these objectives, students will know the natural works and historical sites in the country; students will give examples to cultural characteristics around themselves and in other parts of Turkey; students will compare cultural characteristics of places around themselves and places in other parts of Turkey; students will explain the importance of cultural elements in people living together. However, these subjects do not mean much for a country that is as rich as our country. Only giving two hours a week to teach these subjects is another problem. The $8^{\text {th }}$ unit of $5^{\text {th }}$ grade is about global connections. According to the last three objectives for this unit, students will give examples to shared heritage found in different countries; students will recognize the place of tourism in identifying shared heritage; students will develop perspectives related to the place of tourism in international relations (www.egitek.meb.gov.tr). Not all of the cultural heritages are mentioned in these objectives.

The learning domain of the $7^{\text {th }}$ unit of $7^{\text {th }}$ grade is global connections. According to the $4^{\text {th }}$ objective of this unit, students will recognize the responsibility of humankind in preserving thought, art and literature works, natural artifacts and historical sites as shared heritage elements (www.egitek.meb.gov.tr). Since only two hours of social studies in a week are taught, teachers are trying to teach this objective in just two hours. When the content is examined, it is found that the content is inadequate for a historically rich country like Turkey. This prevents the youth from getting enough knowledge to preserve historical cultural heritage and pass on this heritage. Another problem is that social studies teachers who teach these subjects graduate from university without adequate academic knowledge.

Works related to historical cultural heritages done by non-governmental organizations in the country should not be overlooked. Founded by volunteer academicians in 1990, Foundation for the Protection and Promotion of the Environment and Cultural Heritage promotes local historical cultural heritages to the elementary school students living in each city. Implemented with European partners, Outdoors Education Project is a project that teaches middle school students about historical cultural heritage at outdoors through ecological and sport activities. The project mainly refers to cultural experts, adult educators and adult learners. It is developed and implemented by six European countries, Romania, Italy, Austria, Turkey, Belgium and Norway. The biggest national supporter of these projects from Turkey is The Scientific and Technological Research Council of Turkey. With its cooperation with private institutions, this public center gives funding to many projects, including the ones about historical cultural heritage education. This is really important because the projects the center is funding are teaching about historical cultural heritage that the schools do not teach in detail. However, not all of the new generation can benefit from these projects and their historical cultural heritage sensitivity and awareness levels cannot develop.

\subsection{Historical Cultural Heritage Education in Social Studies Education Departments of Education Faculties}

Although there are many positive works being done regarding preservation of historical cultural heritage in Turkey, works on raising awareness that address the society as a whole are not adequate and the existing works do not achieve the desired outcome. Therefore, a large study and cooperation are needed to address the society as a whole in order to raise awareness. Teachers who provide education from young children to adults should be equipped with the necessary academic knowledge to preserve these heritages. The historical cultural heritage found in Turkey requires this. For this purpose, the government is signing agreements and conventions with 
world organizations.

Many international institutions and organizations, including United Nations Educational, Scientific and Cultural Organization (UNESCO), do works on preservation of historical cultural heritage. At the same time, countries' own public and civil institutions carry out works on preservation of historical cultural heritage. Moreover, a number of international and national conventions are being written. With regard to this issue, Turkey signed the Convention Concerning the Protection of the World Cultural and Natural Heritage in 1983 and the Convention for the Safeguarding of the Intangible Cultural Heritage in 2006 (Oğuz, 2007). In addition to these conventions, Turkey signed Convention for the Protection of the Architectural heritage of Europe in 1989 and European Convention on the Protection of the Archeological Heritage in 1999. Turkey also enacted national Protection of Cultural and Natural Artifacts Law. However, in spite of all the international and national laws, the 429 cultural heritages are not being protected adequately. In this case, the importance of raising citizens' awareness about historical cultural heritage is obvious (Dönmez \& Yeşilbursa, 2014).

In a report ordered by Hamit Zübeyr Koşay in 1948 in Turkey, it was stated that school programs should be organized so that the students love cultural heritages and art and culture should be taught at every school level (Özcan, 2010). In 1970s, Akurgal (1998) expressed that the best way to protect historical works is to make people responsible. Similarly, Uçankuş (2000) stated that teaching these subjects from elementary school through university is important to raise awareness about preservation. Many stated that having the want and awareness to pass on historical artifacts without destroying them is really important (Ahunbay, 2007; Dönmez \& Yeşilbursa, 2014).

This awareness about preservation of historical cultural heritage in the world will be easily raised with education. There are various studies that stressed the relation between preservation of cultural heritage and education and the importance of education in raising cultural heritage awareness (Patrick, 1988; Hunter, 1988; Patrick, 1989; Bektaş, 1992; Corbishley, 2000; Curtis \& Seymour, 2004; Henson, Stone \& Corbishley, 2004; Hereduc, 2005; Alkış \& Oğuzoğlu, 2005; Copeland; 2006). Cultural heritage education includes the preservation, recognition and teaching of all aspects of a society's history, architecture, museums, ancient cities, cultural landscapes, monuments, traditions, photographs, newspapers, documents, court records, family documents, memoirs and handcrafts (Huhta \& Hankis, 1988). The Council of Europe defines heritage education as a teaching approach based on cultural heritage that uses various active educational methods (Council of Europe Committee of Ministers, 1998). Cultural heritage education encourages students to see their surroundings as a lifelong source that they can access information, define social problems and achieve individual success (Hatch, 1988). In addition to helping students focus on heritage sites and traditions, cultural heritage education also helps them to understand why preservation of these sites is important (Copeland, 2004). The first and most important characteristic of cultural heritage education is to increase students' understanding about the history and value of their own natural and man-made environment (Europa Nostra, 2004). Other purposes of cultural heritage education can be summarized as follows (Wilhelm, 2004):

1) To help the students explore their historical and cultural heritage;

2) To help students gain knowledge and experience through exploration of cultural heritage;

3) To help students understand the difference between local and global by going back and forth between them;

4) To help students who usually do not have resources protect themselves for the future by exploration of the past;

5) To educate tomorrow's real, honest and reliable citizens (Dönmez \& Yeşilbursa, 2014).

The researchers stress that cultural heritage education can be given in courses like social studies, history, geography, citizenship, literature, music and visual arts in elementary, middle and high schools. Also, these lessons can be integrated with courses like geometry, physics and chemistry (Hunter, 1988; Patrick, 1989; Wilhelm, 2004; Borman, 2004; Europa Nostra, 2004; Gökmen, 2010). According to Gökmen (2010), historical environment should be incorporated into the schools to increase the quality of it. This proves the importance of social studies. The biggest responsibility in rising cultural heritage awareness in elementary and middle schools falls to the social studies course in our country. For this reason, the following general purposes of Turkish education programs are directly or indirectly related with raising cultural heritage awareness in students (MEB, 2005):

1) Students accept the fact that cultural heritage should be protected and developed by understanding the fundamental elements of Turkish culture and history (Article 5);

2) Students identify the similarities and differences between people, objects, events and facts and understand change and continuity by questioning historical evidences belonging to different periods and places (Article 10); 
3) Students analyze the political, social, cultural and economic interaction between societies in different periods and places (Article 16);

4) Students show sensitivity towards issues concerning their own country and the world by having the awareness that they are part of the humanity (Article 17) (Dönmez \& Yeșilbursa, 2014).

In addition to these general purposes, social studies program is made up of learning strands. A learning strand is a structure that organizes learning by treating related skills, themes, concepts and values as a whole. Learning strands can include one or more than one discipline. For example, the "Culture and Heritage" learning strand includes the disciplines of anthropology, history and citizenship (MEB, 2005). $6^{\text {th }}$ and $7^{\text {th }}$ grade students compare the past cultures with the present cultures by comprehending cultural and aesthetic values. In addition, they gain sensitivity towards preservation of cultural heritage by comprehending the cultural factors and their development processes that have an important role in the formation of national awareness. This learning strand will be integrated with other learning strands like "People, Places and Environments", "Science, Technology and Society", "Individual and Society", "Power, Government and Society”. It will also use fundamental concepts from disciplines like history, geography, archeology, art history, sociology, anthropology, ethnology and economy (MEB, 2005; Dönmez \& Yeşilbursa, 2014). We need to train social studies teachers who have excellent academic knowledge and awareness so that they teach effectively about historical cultural heritage subjects and educate students who will protect and pass on this heritage to the next generations. All the social studies teacher candidates in education faculties of Turkey should take historical cultural heritage education course in addition to history, geography and archeology because social studies teachers are the ones who will educate the future generation that will protect and pass on our historical cultural heritage.

For this study, all the elective courses taught in social studies education programs in Turkey's education faculties were examined and the following results come out. Tourism and World Culture Regions, Turkish Tourism, Tourism Geography, History of Civilizations, Turkish Tourism Geography, History of Turkish Culture, Historical Political and Cultural Geography of Turkey, Ancient Civilizations in Anatolia, Ottoman Culture and Civilization, History and Civilization of Turks before Islam, Mediterranean Civilizations and History of Cyprus, Folklore History, History of Anatolian principalities are taught as elective courses in social studies education programs. However, since these courses are elective, the teacher candidates who take these courses learn about these subjects but the others do not. Since the course contents in different universities are different than each other, not every candidate has adequate knowledge. So, not all social studies teacher candidates have equal knowledge because the courses are elective and the course contents differ. Thus, their knowledge is now enough to teach historical cultural heritage to their own students when they themselves become teachers. The elective courses provided in Turkey's social studies education programs are given in the following table. These courses were identified through a thorough internet search of all the social studies departments in Turkey and later categorized (Table 1). The most taught courses are at the top of list.

\section{Discussion}

Turkey has a thousand year old historical cultural heritage that started from the ancient times. Preservation of this heritage and passing them on to future generations is vital. Aware of this importance, Turkey's institutions, universities and people are working hard. Projects are conducted starting from kindergarten through universities. However, in spite of all these works, there are shortages in preservation of historical cultural heritage. Our people do not just give importance to this heritage but they also destroy it. The following are some of the works being done related to historical cultural heritage:

Istanbul University opened the Management of Cultural Heritage Sites graduate program in 1993. Since Turkey is in the UNESCO 2010 World Cultural Heritage List, it has many cultural and artistic values, ancient sites. Therefore, the purpose of the program is to raise cultural heritage awareness and research the ways to preserve this heritage (www.khas.edu.tr). In addition, Kadir Has University opened a graduate program titled Preservation of Cultural Heritage. The program discusses what, why and how something is preserved. Conservation and restoration is taught with disciplines like history, art history, archeology, ethnology. Students learn preservation through participants from important institutions and from different disciplines. They look at heritage through architecture, urban design, engineering, management, education, and tourism (www.khas.edu.tr). From the $19^{\text {th }}$ century when historical cultural heritage education started, there has been a transformation from apprenticeship to academic education at a scientific level. When we look at the history of preservation education in Turkey, 
Table 1. Elective Courses related to historical cultural Heritage education taught in $2^{\text {nd }}$ and $3^{\text {rd }}$ of social studies programs across Turkey.

\begin{tabular}{|c|c|}
\hline Ranking & Elective Course \\
\hline 1 & Tourism \\
\hline 2 & Tourism Geography \\
\hline 3 & Tourism and World Culture Regions \\
\hline 4 & Cultural Geography \\
\hline 5 & Historical Geography \\
\hline 6 & Cultural Activities \\
\hline 7 & World Culture Regions \\
\hline 8 & World Tourism Geography \\
\hline 9 & History of Civilizations \\
\hline 10 & Ancient Settlements in Anatolia \\
\hline 11 & Historical, Political and Cultural Geography of Turkey \\
\hline 12 & Cultural and Historical Artifacts of Turkey \\
\hline 13 & Tourism of Turkey \\
\hline 14 & Tourism Geography of Turkey \\
\hline 15 & Tourism Problems of Turkey and Sustainable Tourism \\
\hline 16 & History of Turkish Culture \\
\hline 17 & Turkish Culture \\
\hline 18 & General History of Turks \\
\hline 19 & Local History and Culture \\
\hline 20 & Medieval Turkish History \\
\hline 21 & Turkish Nations and Societies \\
\hline 22 & History and Civilizations of Turks before Islam \\
\hline 23 & Culture and Society after 1938 \\
\hline 24 & Research on Turkish World \\
\hline 25 & Ottoman Social and Economic History \\
\hline 26 & Ottoman History and Civilization \\
\hline 27 & Ottoman Culture and Civilization \\
\hline 28 & History of the Seljuks \\
\hline 29 & History and Civilization of the Seljuks \\
\hline 30 & History of Anatolian Principalities \\
\hline 31 & Folklore Science \\
\hline 32 & Language and Culture \\
\hline 33 & Turkish Folklore Culture \\
\hline 34 & Folklore Culture \\
\hline 35 & Folklore Culture Seminar \\
\hline 36 & Turkish Folklore \\
\hline 37 & Culture-Identity-Politics \\
\hline 38 & Poetry Tradition in Turkish Culture \\
\hline 39 & Turkish Folklore Games \\
\hline 40 & Sema Rituals of Mevlevis \\
\hline 41 & History of Turkish Art \\
\hline 42 & History of Turkish Art of Weaving \\
\hline
\end{tabular}

we see that preservation education is not that old. The reason for this is mainly because of bureaucratic approaches and attitudes. There are 63 public and 30 private universities in Turkey. In addition, there are military education institutions and polşce academies. Restoration education in Turkey started for the first time in 1996 at the Faculty of Architecture at Middle East Technical University. Today, in addition to METU, Istanbul Technical University, Mimar Sinan University, Yıldız Technical University, Dokuz Eylül University and Gazi University train specialists in restoration and preservation at an ungraduated level. Also, there are associate degree programs that train intermediate staff in Edirne, Çanakkale, Balıkesir and Zonguldak-Safranbolu. Preservation education in Turkey should be reorganized according to modern and international criteria. One of the most important initiatives towards this was the foundation of "Preservation and restoration of Movable Cultural Artifacts" program in 1993. The program is the first and only program in Turkey. It focuses on the preservation of inorganic artifacts like stone artifacts, earthenware artifacts, murals, mosaics and organic artifacts like wooden artifacts and textiles. In 1996 national Restoration Education Knowledge festival was organized by the Restoration Department of Zonguldak Karaelmas University. The status and problems of the national restoration education were discussed at the festival. The "Settlement Archeology" Department of Middle East Technical University provides a different perspective to the solution of the heritage education problem. Museology is only given at 
Yıldız Technical University. Archeometry is offered at graduate level at Middle East Technical University and Environmental Archeology is offered at undergraduate level at Istanbul University. Offered only at Istanbul University until this year, Geoarcheology will be offered at Çanakkale 18 Mart University and Kadir Has University starting next year (http://www.worldheritageturkey.com/tr/web/14/dunya-mirasi.html). In spite of all these developments at university levels, we cannot say that people's awareness about preservation and passing on historical cultural heritage risen. This is the responsibility of the teachers in a country as culturally rich as Turkey. Because of this, courses like Historical Cultural Heritage Education and Cultural heritage and Tourism should be offered as compulsory courses in the social studies education departments of education faculties. As mentioned before, historical cultural heritage subjects are included in the social studies curricula in elementary and middle schools. Therefore, courses related to these subjects should be made compulsory at social studies education departments of universities. In Turkey, the universities are under the supervision of the Council of Higher Education. This institution oversees universities' all educational activities. Therefore, the course contents taught in education faculties are determined by a commission of the Council of Higher Education. All the education faculties in Turkey offer the same compulsory courses that are determined by this commission. While the elective courses' general areas are determined by the Council, the electives and their contents are determined by the faculty member that offers the courses. These elective courses are sent to the Council and if they are deemed appropriate, these electives are offered in the departments. However, when a faculty member wants a compulsory course to be taught in the department, this course is suggested to the Council through the faculty and university boards. The content of this course is prepared and submitted in a file. Later, a commission including field experts examines the file and decides whether the course is appropriate to be taught. If the Council of Higher Education deems appropriate, this suggested course is sent to all education faculties and these faculties begin to offer the course as a compulsory course.

\section{Conclusion}

The sections on historical cultural heritage of the middle school social studies curricula should be expanded so that students not only recognize and respect Turkish heritage artifacts like Divriği Ulu Mosque, Metropolis archeological Site and Sümela Monastery but also recognize world cultural heritages like the Colosseum (Italy), Acropolis (Greece) and Taj Mahal (India) (http://www.worldheritageturkey.com/tr/web/14/dunya-mirasi.html). While changes in the curricula are made, the awareness and academic knowledge levels of the social studies teachers should be increased. For this, there should be a compulsory course on historical cultural heritage education in social studies departments of education faculties. Expert academicians in historical cultural heritage should inform social studies teachers through projects. Preservation of historical cultural heritage and passing them on to the next generations will be through teachers, particularly social studies teachers.

\section{References}

Ahunbay, Z. (2007). Historic Environmental Preservation and Restoration. (4. Basım). İstanbul: YapıYayın No: 28.

Aktekin, S. (2010). Culturally, The Protection of Natural and Historical Heritage and the Cost to Society: Britain and Turkey Examples. Türk Yurdu, 270, 52-58.

Aktın, K., Karakuş, H., \& Sağlam, H. (2013). Interest and Awareness Levels of the Teacher Candidates from Sinop University about the Historical and Cultural Monuments in Sinop. International Journal of Social Science, 6, 37-59. http://dx.doi.org/10.9761/JASSS1860

Akurgal, E. (1998). Türkiye'ninkültürsorunlarıve Anadolu Uygarlıklarının Dünyatarihindekiönemi. Ankara: Bilgi Yayınevi.

Alım, M. (2009). A Cultural Geography Study: Navruz InIgdır. Doğu Coğrafya Dergisi, 14, 231-238.

Aliağaoğlu, A. (2004). Social-Cultural Heritage Tourismand Examples from Turkey. Ankara Üniversitesi Tür kiye Coğrafya Araştırmaları Merkezi Coğrafi Bilimler Dergisi, 2, 55-70.

Alkış, S. \& Oğuzoğlu, Y. (2005). Importance of Historical Environmental Education in Our Country and Factors Af fecting Its Necessity. Ĕgitim Fakültesi Dergisi, XVIII, 347-361.

Atasoy, S. (1978). Museums as Education Institutions. Arkeoloji ve Sanat, 1, 20-22.

Bektaş, C. (1992). Repair Protection. Istanbul: YEM Yayınları.

Borman, T. (2004). Education at English Heritage. The Hague Forum 2004 (pp. 33-35).

http://www.europanostra.org/documents/ 
Çetin, T. (2010). Perception of Cultural Heritage and Tourism in Cumalikızık Village. Millî Folklor, 22, 181-190.

Cohen, L. Manion, L., \& Morrison, K. (2009). Research Methods in Education (6th ed.). New York: Routledge Taylor \& Francis Group.

Copeland, T. (2004). Heritage and Education: A European Perspective. The Hague Forum 2004 (18-22). http://www.europanostra.org/documents/3

Corbishley, M. (2000). Living Heritage. History Today, 50, 36, 2p, 2c (Ebsco).

Council of Europe Committee of Ministers (1998). Recommendation No. R (98) 5E of the Committee of Ministers to Member States Concerning Heritage Education. 17 March 1998. http://www.coe.int/t/cm/adoptedTexts_en.asp

Curtis, R., \& Seymour, C. (2004). Louisiana Heritage Education Program and Heritage in the Classroom: Children's Attitudes toward Cultural Heritage. Journal of Social Studies Research, 28, 20-24.

Doğaner, S. (2003). Geographical Recourses and Preservation of Heritage Tourism. Coğrafi Çevre Korumave Turizm Sempozyumu (16-18 Nisan 2003). Bildiriler Kitab1, İzmir: Ege Üniversitesi Yayınları, 1-8.

Dönmez, C., \& Yeşilbursa, C. C. (2014). The Effect of Cultural Heritage Education on Students’ Attitudes toward Tangible Heritage. Elementary Education Online, 13, 425-442. http://ilkogretim-online.org.tr

Emekli, G. (2005). The Policies of the Tourism in European Unionand Cultural Tourism in Turkiye. Ege Coğrafya Dergisi, Sayı: 14, 99-107.

Emekli, G. (2006). Geography, CultureandTourism: CulturalTourism. Ege Coğrafya Dergisi, 15, 51-59.

Europa Nostra (2004). Heritage and Education: A European Perspective. The Hague Forum 2004. http://www.europanostra.org/documents/

Giménez, J. E., Ruiz, R. M. Á., \& Listán, M. F. (2008). Primary and Secondary Teachers’ Conceptions about Heritage and Heritage Education: A Comparative Analysis. Teaching and Teacher Education, 24, 2095-2107. http://www.sciencedirect.com/science/journal/0742051X/24 http://dx.doi.org/10.1016/j.tate.2008.02.017

Gökmen, H. (2010). Architecture and Children Works: Structural Environmental Education. Mimarlık, 352. http://www.mimarlikdergisi.com/

Gülcan, B. (2010). Body of Cultural Tourism in Turkey and Need of Product Differentiation Based on Tangible Cultural Assets. Işsletme Araştırma Dergisi, 2, 99-120.

Güleç, S., \& Alkış, S. (2003). Communicational Dimension of Museum Field Trips in Social Studies Education. Uludağ Universitesi Ĕ̈itim Fakültesi Dergisi Cilt, 17, 63-78.

Gümüş, N., \& Adanalı, R. (2011). The Attitude and Behavior of Students in High School towards Historical and Cultural Heritage in Buca (Izmir). Buca Eğitim Fakültesi Dergisi, 30, 87-102.

Güvenç, B. (1994). Human andCulture (p. 48). Istanbul: Remzi Kitapevi.

Hatch, K. (1988). A Heritage at Risk: An Agenda for the Future. The Journal of Museum Education, 13, 4-7.

Henson, D., Stone, P., \& Corbishley, M. (2004). Education and the Historic Environment. New York: Routledge.

Herbert, D. (1995). Heritage, Place Leisure and Tourism, Heritage, Tourism and Society (pp. 1-20). London: Mansell Publishing.

Hereduc (2005). Heritage in the Classroom: A Practical Manuel for Teachers. http://www.hereduc.net/hereduc/date

Hooper-Greenhill, E. (1994). Museum Education: Past, Present and Future. In R. Milles, \& L. Zavala (Eds.), Towards the Museum of the Future (pp. 133-146). London, New York: Routledge.

Huhta, J. K., \& Hankins, J. S. (1988). Approaching Heritage Education from Every Angle. The Journal of Museum Education, $13,13-15$.

Hunter, K. (1988). Heritage Education in the Social Studies. ERIC ED 300306. www.eric.ed.gov

Işı 1 , H. (2008). The Effects of Combination of the History Subjects with Local History on the Success of Students in Primary School. Uluslararası Sosyal Araştırmalar Dergisi, 290-310.

Karasar, N. (2014). Scientific Research Method, (26th ed., p. 77). Ankara: Bask1 Nobel Akademik Yayıncılık.

Keleş, R. H. (1997). Environmental Science (p. 21). Ankara: İkinciBaskı, İmge Yayınevi.

Kilcan, B., \& Akbaba, B. (2013). Examining Students’ Perceptions on Sensitivity to Cultural Heritage Value in Social Sciences Teaching Program. Zeitschriftfürdie Welt der Türken, 5, 113-138.

MEB (2005) Elementary Social Studies 6-7. Classes Curriculum and Instruction Manual (Draft Edition). Ankara: Talim Terbiye Kurulu Başkanlığı.

Mercin, L. (2002). Evaluation of Art School Teachers' and Administrators' Perception Related to Using Museums for Art Education. Ankara: Yüksek Lisans Tezi. 
Oğuz, O. (2007). UNSECO, Culture and Turkey. National Folklore, 73, 5-11.

Ott, M., \& Pozzi, F. (2008). ICT and Cultural Heritage Education: Which Added Value? In M. D. Lytras et al. (Eds.), WSKS, LNAI 5288 (pp. 131-138). Berlin Heidelberg: Springer-Verlag.

Ott, M., \& Pozzi, F. (2011). Towards a New Era for Cultural Heritage Education: Discussing the Role of ICT. Computers in Human Behavior, 27, 1365-1371. www.elsevier.com/locate/comphumbeh http://dx.doi.org/10.1016/j.chb.2010.07.031

Özcan, Ö. (2010). Notes on Turkish Museums after the Republic. Türk Yurdu, 30, 30-34.

Özgüç, N. (2003). Tourism Geography Properties and Regions. İstanbul: Çantay Kitapevi.

Patrick, J. J. (1988). Historic Preservation and School curriculum. Paper Presented at the Symposium on Heritage Education, Washington DC, 11 May 1988, ED 300289.

Patrick, J. J. (1989). Heritage Education in the School Curriculum. Paper Prepared for the National Trust for Historic Preservation and the Waterford Foundation, Waterford, 16-18 November 1989, ED 315333.

Şahan, M. (2005). Museumsand Education. Türk Eğitim Bilimleri Dergisi, Cilt: 3, sayı: 4 (487-501). http://www.tebd.gazi.edu.tr/index.php/tebd/article/viewFile/335/317

San, İ. (1998). Museum Education Science How to Improve? Milliyet Sanat, 444.

Sternberg, S. (1989). The Art of Participation. In N. Berry, \& S. Mayer (Eds.), Museum Education History, Theory and Practice (pp. 257). Reston, VA: The National Art Education Association Editors.

Stone, P. (2004). Introduction: Education and the Historic Environment into the Twenty-First Century. In D. Henson, P. Stone, \& M. Corbishley (Eds.), Education and Historic Environment (pp. 1-10). New York: Routledge. http://dx.doi.org/10.1017/cbo9780511617089.002

www.egitek.meb.gov.tr

Taş, A. M., \& Yıldız, N. (2015). Metaphors about the Concept of "Museum” of 4th Graders in One Elementary School in Turkey. International Journal of Education, 7, 19-30.

Tümertekin, E., \& Özgüç, N. (1997). Human Geography (Human Culture, Space), Çantay Kitapevi, İstanbul.

Tümertekin, E., \& Özgüç, N. (2015). Human Geography (Human Culture, Space), Çantay Kitapevi, 15. Bask1, İstan bul.

http://www.worldheritageturkey.com/tr/web/14/dunya-mirasi.htm

Uçankuş, H. T. (2000). One of Humanity and Civilization Science of Archeology: Prehistoric Era up to the Persians from Anatolia. Ankara: Kültür Bakanlığı Yayınları.

UNESCO (1972). Convention Concerning the Protection of the World Culturaland Natural Heritage. 14.02.1983 tarih ve 17959 sayılı Resmi Gazete.

UNESCO (1999). World Culture Report: Culture, Creativity and Markets. France.

Uygur, S. M., \& Baykan, E. (2007). Culture Tourismand Effect of Cultural Tourism and Tourism on Cultural Wealth. Ticaret ve Turizm Eğitim Fakültesi Dergisi, 2, 30-48.

Wilhelm, N. (2004). Voyage to the Heart of the Heritage: Our Heritage Explained to Children. Heritage and Education: A European Perspective. The Hague Forum 2004 (25-27). http://www.europanostra.org/documents/

Yasin, M. (2007). Koruma Amaçlıİmar Planlarının Yapılış Süreci. E-akademi Hukuk, Ekonomive Siyasi Bilimler Aylık İnternet Dergisi, Say1: 59.

Yeşilbursa, C. C. (2013). The Sixth Grade Students’ Views toward Tangible Heritage. Kastamonu Education Journal, 21, 405-416. www.kefdergi.com/pdf/21_2/21_2_1.pdf

Zimolzak, C. E., \& Stansfield, C. A. J. (1983) The Human Landscape, Geoğraphy and Cultural. Ohio. 